\title{
Selecting a Monetary Indicator-Evidence from the United States and Other Developed Countries
}

\author{
by MICHAEL W. KERAN
}

T

HERE IS a long tradition of comradeship between central bankers of different countries. This is due not only to the similarity of professional backgrounds of central bankers but, perhaps more importantly, to the similarity of monetary tools and technical problems in the conduct of monetary policy.

Most central banks have a common set of monetary tools: ${ }^{1}$

(1) the discount rate, or the price at which it loans reserves to the banking system;

(2) open market operations and "window guidance," or the quantity of direct reserves it provides; and

(3) reserve requirements, or the amount of reserves that the banking system is required to hold as idle balances and therefore cannot use for loans and investments.

Which of these tools will be dominant depends upon the institutional and financial conditions of each country. In the United States, with its well-developed short-term financial markets, the primary monetary tool is Federal Reserve open market operations. In Germany, where the short-term money market is not

*An earlier version of this paper was presented on June 10 , 1970 , in Seoul, Korea, on the occasion of the twentieth anniversary of the Bank of Korea. The author gives special thanks to Professors Karl Brunner and Allan Meltzer, and to his colleagues Leonall Andersen, Christopher Babb and Keith Carison, for helpful comments.

1These monetary tools represent indirect controls of the central bank on the banking system, because they constrain only the total balance sheet of the banking system, and the banks are free to adjust the individual components of their portfolio.

The central bank may also have monetary tools which directly affect specific sectors of the banking system's balance sheet. Interest rate ceilings on time deposits constrain a segment of the banking system's liablities; quantitative limits on the amount of business loans restrict a component of a bank's assets. The discussion with respect to the indicator question applies to both direct and indirect central bank tools. well developed, and where large reserve injections come from balance-of-payments surpluses, the primary monetary tool is changes in reserve requirements (Mindestreservepolitik). In Japan, where commercial banks are in large and continuous debt to the central bank, the primary monetary tool is rationing central bank credit through the discount window (Madoguchi Shido). In Korea, the primary tools are reserve requirements and rationing at the discount window (Chan-gu Kytu-jai).

Once monetary policy is determined and the monetary tools activated, the next question central bankers face is "are net monetary influences on the economy moving in line with policy?" In a world of uncertainty, this question can only be answered in the context of a properly specified indicator of monetary influence on the economy.

This article will (1) briefly discuss the need for an indicator and the method of testing alternative indicators; (2) develop the criteria of a good indicator; (3) present statistical evidence regarding which indicator has given the most consistently correct information for various periods of American history and for recent experience of other developed countries; and (4) consider the general factors which would make one indicator superior to another.

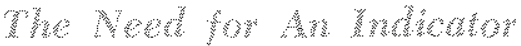

An indicator is defined here to be some readily observable economic time series which can be used to "scale" monetary or fiscal influences on economic activity. If the indicator shows an increase, we want to be able to say with some confidence that monetary or fiscal influences are easier or tighter, depending on what sign the indicator is postulated to have. 
In a world of perfect knowledge of the financial and economic interrelationships in an economy, one would not need an indicator of monetary infuence. Given a particular monetary policy goal, stuch as to restrict total demand, the policymaker could directly link the manipulation of his monetary tool (open market operations, reserve requirements, or the discount rate) to a desired change in total demand. This would be possible because, with perfect knowledge of the relationships in the economy, the policymaker would know the exact linkage between his manipulation of the monetary tool and its consequence with respect to total demand.

Unfortunately, we do not have perfect knowledge about the links between monetary tools and financial markets or between financial markets and real markets. We know relatively little about the transmission mechanism between central bank actions and the final effect on the economy. This uncertainty is not only due to a lack of statistical data, since it exists in all countries irrespective of whether they have strong or weak statistical gathering services.

An example may help illustrate the problem of uncertainty in the implementation of monetary policy. Suppose the United States wishes to follow a restrictive monetary policy. To do this the Federal Reserve may raise the discount rate, raise reserve requirements, or sell Govemment securities on the open market. However, any of these movements in the monetary tools may not by themselves lead to tight monetary influences on the economy. A rise in the discount rate may not raise the relative price of central bank credit if, because of an increase in the demand for credit, money market interest rates rise by as much as, or more than, the rise in the discount rate. An increase in reserve requirements designed to impound reserves may be offset by an increase in Federal Reserve float, because of a rise in bank transactions. The reserves lost by the banking system through Federal Reserve selling of Government securities may be neutralized by a gold inflow.

Some of these neutralizing influences can be accounted for and offset by the central bank. However, given the current state of knowledge about economic relationships, many other factors which could neutralize Federal Reserve actions are not known. The central bank needs a summary indicator of net monetary influences on the economy as a check against whether the manipulation of its monetary tools is achieving the previously established goals.
By observing the movement of the indicator, the central bank should be able to determine whether monetary influences are expansionary, contractionary, or neutral. If the indicator shows monetary influences are expansionary, and policy calls for contraction, then the monetary tools can be manipulated in a more contractionary way. If the monetary indicator is moving in the same direction as that called for by policy, then the monetary tools need not be manipulated as vigorously as in the previous case.

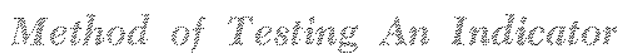

The indicator problem can be considered either in the context of a large structural model or in the context of a single equation, reduced form approach. The single equation approach will be used here. ${ }^{2}$

The single equation approach to the indicator issue has a number of virtues. First, it includes most of the monetary and fiscal variables that are components of the economic theories developed in most textbooks, and which are used in the estimations of most structural econometric models. Generally, it is these monetary and fiscal variables which are, within the framework of these large models, the dominant factors influencing economic activity. Thus, if the monetary and fiscal variables are properly specified, the single equation approach will include the generally recognized major factors in economic stabilization. Second, there is a considerable degree of uncertainty, given our lack of knowledge about the economic world, as to the major channels by which these monetary and fiscal variables influence the economy. In consequence, it is a useful research strategy to consider these issues by employing the single equation approach where the transmission mechanism is not

\footnotetext{
In the case of a large structural model, a theory is stated about the interaction of decision-making units in the economy. Such a theory would, naturally, include information about how monetary and fiscal policy tools affect economic activity. The monetary or fiscal indicator would be implieit in the hypothesized structure of the economy and, by standard theoretical analysis, could be made explicit. Different indicators could be derived analytically from alternative theories about the structure of the economy. If we are not certain which of the hypothesized economic structures is "true," then even if we have the optimal indicator for each structural theory, we do not necessarily have the "true" indicator of monetary or fiscal infuences. For an example of analytically deriving monetary indicators from a number of structural econometric models, see Richard Zecher, "An Evaluation of Four Econometric Models of the Financial Sector," Dissertation Series No. 1, Federal Reserve Bank of Cleveland Economic Papers (January 1970).
} 
specified. ${ }^{3}$ Third, this approach is consistent with a wide range of theories (hypotheses) about the structural interrelations in the economy.

The key to the single equation approach is the proper specification of the monetary and fiscal variables. On the fiscal side, there is general consensus that some measure of changes in government spending and tax rates transmits important fiscal influences. On the monetary side, there is a controversy as to the appropriate measure of monetary influences. Some economic theorists and model-builders use various market interest rates as a measure of monetary influences; others use various monetary aggregates. To help resolve which class of measures provides the better indicator of monetary influences, a statistical test is employed. For this test, a representative of each class of indicators is selected; a long-term interest rate and the narrowly defined money stock. The test would allow us to assert one of three propositions: (1) the money stock is superior to long-term interest rates as an indicator; (2) long-term interest rates are superior to the money stock as an indicator; or (3) neither the money stock nor interest rates are clearly superior as an indicator,

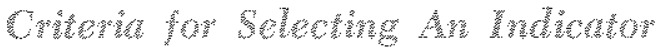

There are no generally accepted criteria of a good indicator with the single equation approach. Three criteria are suggested here which are plausible, but not necessarily exhaustive: (1) to be useful as a guide to central bank policy implementation, an indicator should be responsive to the monetary tools of the central bank; (2) in order to interpret movements in the indicator as expansionary or contractionary, it should have a theoretically unambiguous association (or sign) with total demand; (3) to be of practical use to central bankers, it should have a high degree of statistical association (with the theoretically expected sign) with total demand. If the indicator changes in value today, we want to be able to predict with some degree of confidence what will happen to total demand in the future.

How do the money stock and interest rates compare with the criteria of a good indicator? With respect to the first criterion, the central bank's ability to sub-

3This, of course, would only give a first approximation measurement of impact, which could later be refined when we have greater confidence in the structural models. Indeed, the results of the single equation estimates could help guide structural model-builders in the most fruitful direction. stantially affect interest rates or the money stock is widely accepted among economists. This is based on the general proposition that because a central bank has, in effect, unlimited financial resources, it can determine the value of any financial variable, including interest rates or the money stock (but not both simultaneously). There has been a relatively limited amount of empirical work directed to the question of responsiveness of monetary indicators to central bank tools, but what has been done supports this general proposition. ${ }^{4}$

It is also not hard to find theoretical justification for the role of both interest rates and the money stock as an important element in the transmission of central bank actions to the rest of the economy. Both the Keynesian Income-Expenditure Theory and the Modern Quantity Theory of Money place money and interest rates in strategic roles. ${ }^{5}$ These two theories differ substantially with respect to how money and interest rates operate on the economy, but do not differ on the proposition that both variables are important. In the Keynesian theory, the money stock is positively associated and interest rates are negatively associated with economic activity. In the Quantity theory, the money stock is also positively associated with economic activity; however, the interest rate link to economic activity is ambiguous, because the link between money and interest rates is negative in the short run but it could be positive in the long rum.

Both interest rates and the money stock pass the first two tests of a good indicator, which leaves the third criterion for differentiating between money and interest rates. Which of these two variables has been observed to have the closest statistical association (with the expected sign) with economic activity?

\footnotetext{
$\star$ See A. Burger, An Explanation of the Money Supply Process, Wadsworth Publishing Company (forthcoming): Keran and Babb, "An Explanation of Federal Reserve Behavior (193368)," this Review (July 1969); Allan Meltzer, Controlling Money, this Review (Nay 1969); John Wood, “A Model of Federal Reserve Behavior," Staff Economic Study No. 17, Board of Governors of the Federal Reserve System; and Zecher, An Evaluation of Four Econometric Models of the Financial Sector, G. Kaufman, "Indicators of Monetary Policy," National Banking Review, June 1967.

oUntil recently, most econometric models along Keynesian tines have ignored the explicit role of money. However, more recent work, specifically the MIT-FFB model, has included monetary aggregates. Keynesian economic theory is compatible with either a monetary or interest rate measture of central bank actions.

The quantity theory of money also treats interest rates as the strategic price variable which transmits monetary influ ences to the rest of the economy. See Milton Friedman "The Quantity Theory of Money - A Restatement," in Studies in the Quantity Theorty of Monet, (Chicago: University of Chicago Press, 1956), pp. 3-21.
} 


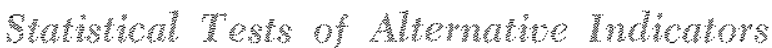

A number of recent studies in this Review have measured the relative impact of monetary and fiscal influences on economic activity in the United States and in other developed countries. ${ }^{\text {i }}$ The single equation tests were of the following general form:

where

$$
\Delta \mathrm{Y}=\alpha_{0}+\alpha_{1} \Delta \mathrm{M}+\alpha_{2} \Delta \mathrm{F}+\mathrm{e}
$$

$\mathrm{Y}$ is a measure of economic activity (total demand)

$M$ is a measure of monetary influence

$F$ is a measure of fiscal influence

$\Delta$ is quarterly change

The symbol $\alpha_{1}$ stands for the coefficient relating monetary influences to economic activity. The symbol $\alpha_{2}$ is the coefficient relating fiscal infuences to economic activity. The symbol $\alpha_{0}$ represents the coefficient for the trend value of all other influences on economic activity. The symbol e represents the error term or nontrend values of all other influences on economic activity.

These earlier studies found this single equation approach useful, as a first approximation, in measuring monetary and fiscal influences on total demand.

This same single equation approach is used here to test alternative monetary indicators. One difference from earlier studies is that alternative monetary indicators must be estimated in separate equations, because they are conceptually measuring different aspects of the same phenomenon. ${ }^{7}$

All variables are measured as quarterly differences or changes from one quarter to the next. The data are drawn from fifty years of American history (1919/II to $1969 /$ IV), divided into a total and five sub-periods, and the postwar periods of five other developed countries: Canada, Germany, Japan, South Africa, and the United Kingdom. ${ }^{8}$ All equations were estimated using the Almon distributed lag technique (see Appendix for discussion).

\footnotetext{
The rationale for this approach to empirical estimation has been discussed before and will not be repeated here. The interested reader is referred to Andersen and Jordan, "Monetary and Fiscal Actions: A Test of Their Relative Importance in Economic Stabilization," this Review (November 1968) DeLeeuw and Kalchbrenner, "Comment" this Review (April 1969), and Keran, "Monetary and Fiscal Influences on Economic Activity - The Historical Evidence," this Review (November 1969).
}

${ }^{7}$ Fiscal indicators are included in the statistical estimations, but are not considered explicitly in the text which is concerned only with monetary indicators. If the fiscal variables had not been included, the estimated coefficients of the monetary variables could have been biased of their statistical significance over- or under-stated.

spetailed description of data and sources is given in the Appendix.
For each country, and for each period of American history, three tests were performed, and the results are summarized in Tables I, II, and III of the Appendix. The first test consisted of regressing changes in economic activity against changes in Government spending, the Government tax rate," and the money stock. Government expenditures and tax rates are the indicators of fiscal influence, and the money stock is the indicator of monetary influence. The second test was identical to the first test, except that changes in longterm interest rates were substituted for the money stock as the indicator of monetary influence. In the third test, the level of long-term interest rates was used for the monetary indicator. ${ }^{10}$

Several interesting observations could be made on the basis of these statistical results. However, just one question will be considered - whether the money stock or interest rates is a more reliable indicator of monetary influence. According to the discussion in the previous section, the monetary variable which is most consistent in predicting future movements in economic activity is a superior indicator. Predictable association of one of a number of independent variables with respect to the dependent variables is measured by the " $t$ " statistic. A " $"$ " statistic of 1.96 or larger for a coefficient is considered statistically significant within the conventional 95 per cent confdence intervals. A " $\mathrm{t}$ " statistic of less than 1.96 is not considered statistically significant. The higher the " $\mathrm{t}$ " statistic, the greater confidence one has that the estimated coefficient is drawn from the same "universe" as the "true" coefficient. To facilitate comparisons of the " $\mathrm{t}$ " values for the monetary "sum" coefficients in the Appendix, they have been grouped into Table I.

Of the eleven test periods - six from the United States and five from other countries - only in two

TTotal tax receipts are a function of both the level of income and the average tax rate established by the Government. Only the tax rate can be considered a policy variable, because changes in tax receipts due to changes in GNP are not direckly controllable by Government action. To take accourt of this consideration, the tax variable in this study is computed as an average tax rate on all sources of income as follows:

$$
\Delta \mathrm{tx}=\Delta\left(\frac{\mathrm{T}_{\mathrm{X}}}{\mathrm{Y}}\right) \cdot \mathrm{Y}
$$

where $T x$ is total receipts and $Y$ is nominal GNP.

The change in the tax rate is scaled by the level of (Y) to convert it into a bilions of dollars equivalent.

1.T There are two exceptions in the use of long-term rates, Japan and South Africa. A short-term rate was used for Japan because the long-term rates are subject to informal interest rate ceilings imposed by the government. A shortterm rate was used for South Africa becanse no suitable long-term rate was avallable. 


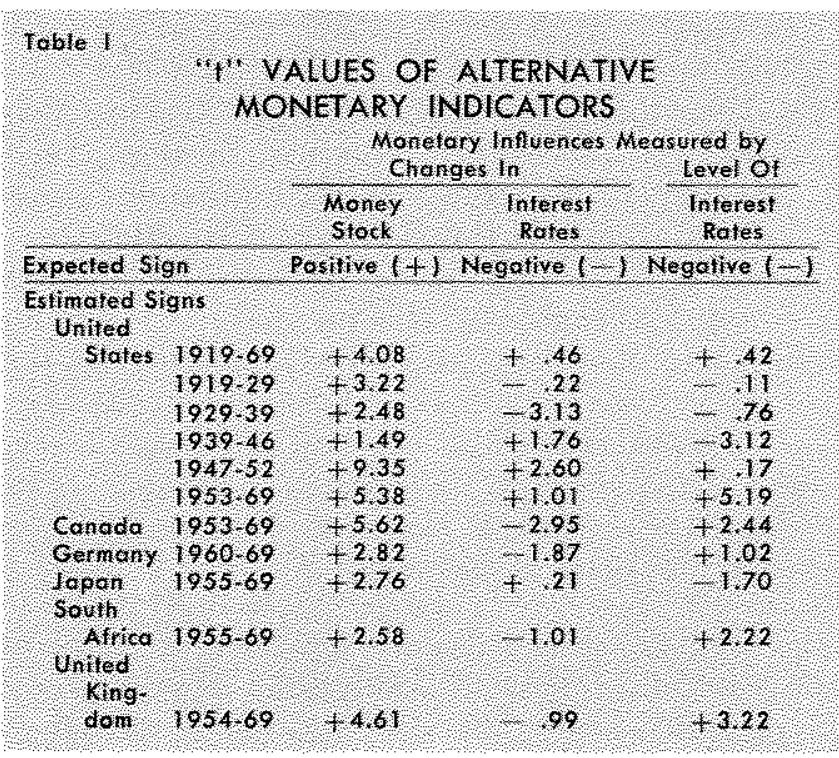

periods did changes in interest rates (column 2) have a statistically significant negative value (U.S. $1929-39$ and Canada). In the other nine periods, the change in the interest rate coefficient was significantly positive in one period (U.S. 1947-52), and statistically insignificant in the eight other periods. Clearly, changes in interest rates do not give a systematic or consistent indication of monetary influences on economic activity and thus are not a reliable indicator.

The statistical test was also performed using levels of interest rates and first differences for the other variables (column 3). These results are less satisfactory than using changes in interest rates. Of the eleven test periods, only one had a statistically significant and negative coefficient. That result occurred for the United States in 1939-46. Of the other ten cases considered, four are statistically significant but of the wrong sign (positive), and six are statistically insignificant.

The money stock, on the other hand, had a positive relationship with economic activity in all eleven periods and was statistically significant in all but one period, World War II (U.S. 1939-46). In spite of the wide diversity of institutions and economic circumstances represented in the different time periods and different countries, changes in the money stock have almost always led to a predictable change in economic activity in the direction consistent with economic theory.

With respect to the propositions considered on page 10 , the one which is most consistent with the evidence just presented is (1) the money stock is superior to long-term interest rates as an indicator of monetary influence. It is possible that a different pair of monetary indicators would not have supported the superiority of a monetary aggregate over an interest rate measure. However, such a result is not likely, because most monetary aggregates move in line with the money stock, and most interest rates move in line with the long-term bond rate. In this type of test, it is umnecessary for the magnitudes of the movements to be similar.

A second test of alternative monetary indicators consists of looking at the average quarter-by-quarter pattern of their association with economic activity, in contrast with their total (sum) association with economic activity (Table I). The charts on the next page present the results of such a test for changes in money and changes in interest rates, where each chart can be thought of as representing the pattern of statistically estimated coefficients relating changes in money (the solid line) and changes in interest rates (the dotted line) to changes in economic activity. Because the money stock and interest rates are measured in different dimensions, the estimated coefficients have been multiplied by the ratio of the standard deviation of the independent and dependent variables, so that the coefficients can be compared directly. When the estimated coefficients are thus modified, they are referred to as Beta coefficients. ${ }^{11}$

The pattern of the Beta coefficients for the money variable $(\Delta M)$ is very similar for all periods and countries represented. The coefficients have a consistently positive value through most of the time periods. If there are any negative coefficients on the money variable, they appear in the longest lag time period, usually in excess of $t-4$. The only exception to this "standard" patterm is the United Kingdom, where there is one virtually zero value of the $\Delta M$ coefficient in the middle of a pattern of positive coefficients.

The Beta coefficients for changes in interest rates $(\Delta \mathrm{R})$ also have a degree of consistency. However, it is not the kind of consistency which increases policymakers' confidence in interest rates as an indicator. In all but one case, changes in interest rates show an initial positive association with economic activity which only gradually diminishes and becomes a negative association after three to five lagged quarters. The interest rate coefficient has the theoretically expected negative association with economic activity consistently only in the case of the United States from

1IThe results for the War and immediate Postwar periods for the United States and South Africa are omitted from the chart, because of space limitations. The pattern of the Beta coefficients for the omitted periods is quite similar to that of the included periods. 


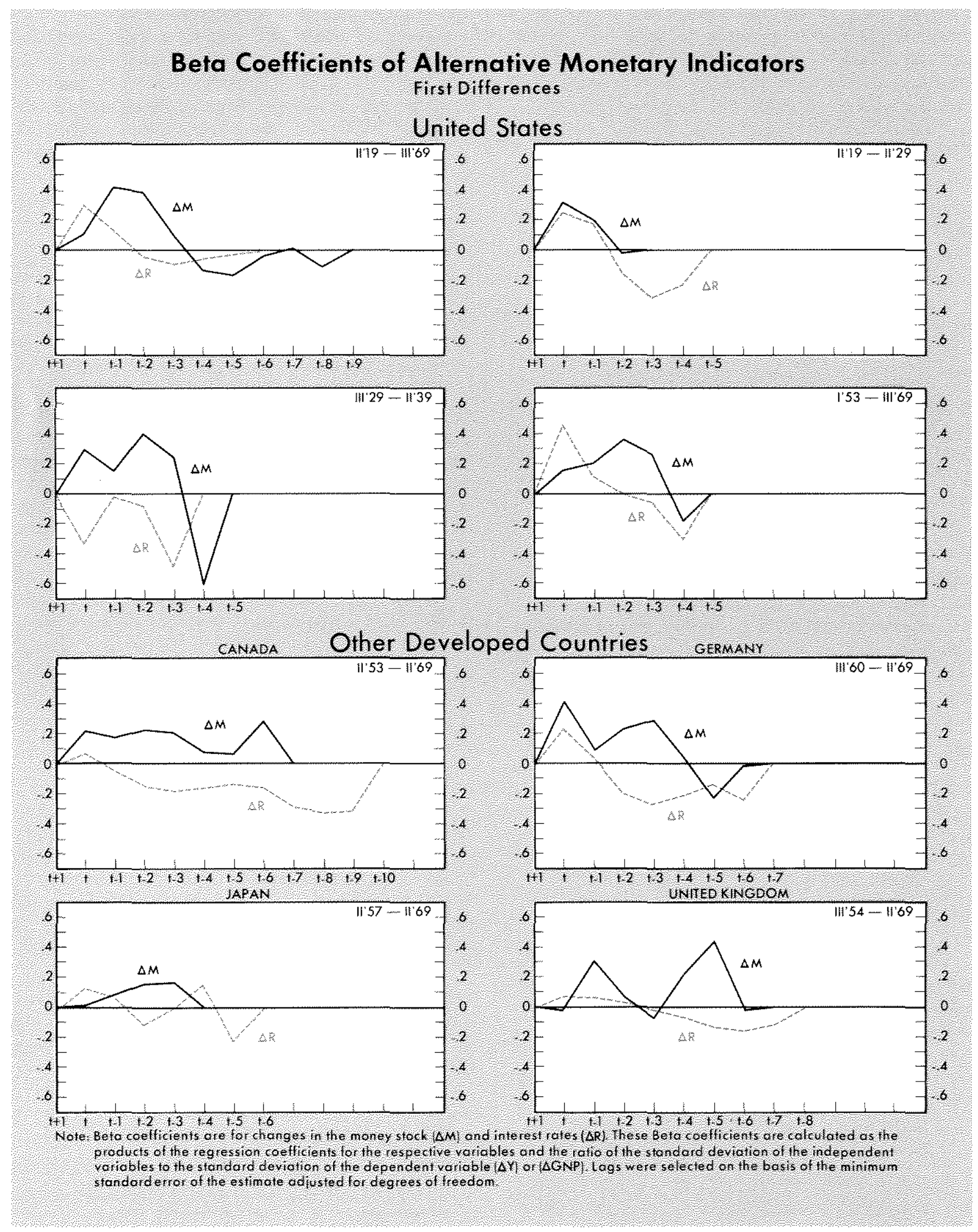


1929 to 1939. In the Canadian case, interest rates have a small positive influence in the initial quarter, and consistently negative influences in all subsequent quarters. It is not surprising that these two cases are also the only ones where the sum coefficients were statistically significant and negative, as described in Table I, column 2.

In the other six cases in the chart, the pattern of the interest rate coefficients is such as to virtually wash out any consistent effect on economic activity. The early positive influences are matched by the later negative influences. This is also consistent with Table I, column 2, where the value of the " $\mathrm{t}$ " statistic indicated that these same six cases had statistically insignificant sum coefficients.

The results presented in Table $I$ and the chart are highly consistent with each other, and provide a strikingly strong case that monetary influences, measured by changes in the money stock, have a more predictable and uniform patterm of effect on economic activity than monetary influences, measured by changes in long-term interest rates.

What do these results imply for the monetary policymaker? If he desires to minimize his errors in predicting the effects of his actions on the economy, he will use the money stock as an indicator of monetary influence. This selection is not dependent on his acceptance of a "Quantity Theory" view of the transmission mechanism. It is equally consistent with a Keynesian view of the transmission mechanism which also postulates a positive association of money with economic activity. Rather, the selection is based on the empirical observation that interest rates have proven to be a misleading indicator in most periods, while the money stock has proven to be an accurate indicator in virtually all periods. ${ }^{12}$

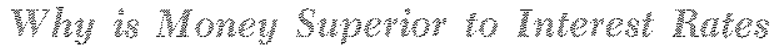 as an Indeator:}

The empirical results just discussed should not be interpreted as denying the central role of interest rates in transmitting monetary influences to the rest of the economy. The large body of theoretical literam ture on the paramount role of interest rates is not in dispute. Most monetarists acknowledge the role of interest rates in the transmission mechanism.

\footnotetext{
12For another study along similar lines see M. Hamburger "Indicators of Monetary Policy: The Arguments and the Evidence," The American Economic Review, May 1970, and M. Willms, "An Evaluation of Monetary Indicators in Germany," in K. Brtunner, ed,, Proceedings of the First European Conference on Monetary Theory and Monetary Policy. forthcoming.
}

In a world of perfect knowledge about the financial and economic structure, both the money stock and interest rates would give identical information about monetary influences on the economy. ${ }^{13}$ The indicator problem arises because there is ignorance at the empirical level about exact specification of the linkages of monetary and other variables in the economy and the time lags associated with them. The evidence which was considered above suggests that the money stock has an overwhelmingly more predictable association with economic activity than interest rates.

Knowledge is one of our scarcest resources, and it apparently takes less knowledge to properly evaluate the impact of the money stock than the impact of interest rates. Conversely, to see the workings of interest rates it takes more knowledge of the workings of the economy than we currently have. There are a number of possible reasons for this state of affairs:

1. Difference between theoretical and actual measures. The range of interest rates which are theoretically relevant in indicating monetary influence on economic activity is much broader than that available in the published interest rate series. The transmission of monetary impulses to the rest of the economy operates through changing prices of a wide range of assets and liabilities, which is equivalent to changes in their associated interest rates. The value of financial assets reflected in the yield on any one type of bond may be too narrow to represent the wide spectrum of assets and liabilities represented in the balance sheets of households and firms which transmit monetary influences.

The measured money stock, on the other hand, is a much more complete enumeration of the liquidity position of all households and firms. Only commercial bank demand deposits and currency issued by the central bank and Government can perform the role of a medium of exchange. Even other financial institutions must hold their working balances as demand deposits in a commercial bank. Therefore, the observed money stock series comes closer to a theoretical measure than the observed interest rate.

2. Difference between real and nominal values. It is generally asserted that it is changes in real interest rates which affect economic activity, but only changes in nominal interest rates are actually measured and reported. The difference between real and nominal interest rates is the result of the change in prices which is expected to occur between now and the maturity of the financial in-

\footnotetext{
${ }^{13}$ See Karl Brunner and Allan Meltzer "The Nature of the Policy Problem" in Targets and Indicators of Monetary Policy, (San Francisco: Chandler Publishing Co., 1969).
} 
strument. ${ }^{14}$ Measurement of these expected price changes is both conceptually and empirically a difficult process, subject to many errors. If nominal interest rates are rising because of expected inflation in the future, the real interest rate may actually be unchanged or falling. Thus, to evaluate monetary actions in a period of inflation or deflation by looking at nominal interest rates may be misleading. This problem does not arise with measurements of the money stock, because in its most generally used form it is nominal values of money which influence nominal values of economic activity.

3. Confusion between supply and demand. Even if one could measure real interest rates, the change in interest rates may be due to a change in the demand for credit rather than to a change in the supply of credit, engineered by the central bank. In a period of economic expansion, the demand for credit increases, which pushes interest rates up. In a period of economic decline, there is typically a reduction in the demand for credit, which pushes interest rates down. Such movements in interest rates are not the result of central bank action but of feedback from the rest of the economy. Yet, if interest rates are used as an indicator of monetary influence, it would appear as if the central bank has taken countercyclical actions when, in fact, it may have taken no action at all.

This problem is not as serious when the money stock is used as an indicator. Most studies on the determinants of the supply of money lead to the conclusion that central bank operations dominate the money stock and tend to offset demand-induced changes in the money stock. ${ }^{15}$ In other words, the behavior of the public, acting on the demand side of the market, does not bias the money stock as an indicator of monetary influence as much as it does interest rates.

14The difference between real and nominal interest rates can

be presented as follows: $r^{*}=r-p^{e}$, where $r^{*}$ is the real interest rate, $r$ is the nominal interest rate, and $\dot{p}^{e}$ is the rate of change in expected prices of goods and services over the life of the finarcial assets. If price expectations are formed very slowly, then the gap between real and nominal interest rates will be small. Until quite recently this was the generally held position among economists. However, Yohe and Karnosky (this Review December 1969) have developed new evidence which indicates that price expectations are formed quite rapidly, thereby creating a substantial gap between real and nominal interest rates even during relatively short periods of inflation and deflation.

15See John Wood "A Model of Federal Reserve Behavior" Staff Economic Studies No. 17, Board of Governors, 1968. Also, "An Explanation of Federal Reserve Actions," this Review, July 1969 . "Reply to Comments on the St. Louts Position," August 1969, and "Comment," May 1970.
4. Greater stability in the demand for money than in the demand for commodities. If our current state of knowledge allows us to more accurately predict the demand for money than the demand for goods and services, then the money stock will be more closely related to economic activity than interest rates in any statistical analysis. ${ }^{10}$ This point can be illustrated in a standard Keynesian LM-IS framework, as in Figure $\mathbf{I}$.

\section{Figure I}
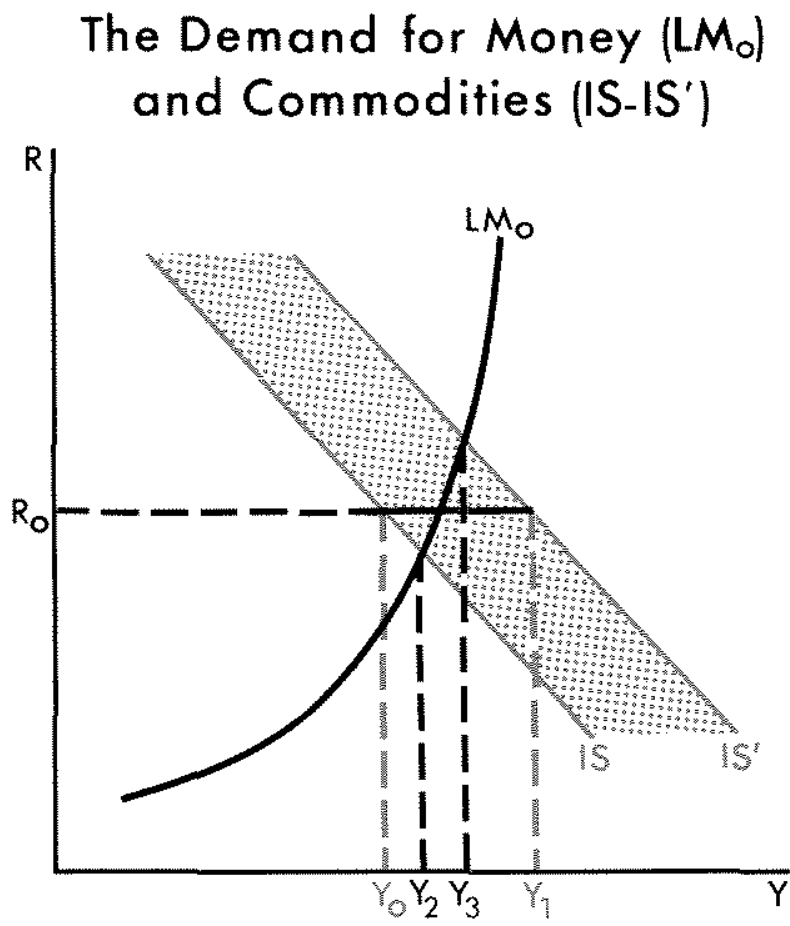

If the demand for money is well specified, then the locus of points representing the LM curve can be described by a line $\left(\mathrm{LM}_{0}\right)$. If the demand for commodities, however, has a large random (stochastic) element, the IS curve can be described only as a band, the dimensions of which are IS - IS'. In this circumstance, the link between any interest rate $R_{0}$ and income would be represented by the gap $Y_{0}-Y_{1}$. On the other hand, the relationship between any given money stock $\mathrm{M}_{0}$ (which is implied by a given LM curve) and income would be represented by the band $Y_{2}-Y_{3}$. Because the spread between $Y_{0}$ and $Y_{1}$ is greater than the spread between $Y_{2}$ and $Y_{3}$, the degree of statistical association between changes in $R$ and changes in $\mathrm{Y}$ would be less than between changes in $M$ and changes in $Y$.

\footnotetext{
16The rationale for the greater stability for the demand for money than the demand for commodities is presented by Willam Poole in "Optimal Choice of Monetary, Policy Instruments in a Simple Stochastic Macro-Model." Quarterly Joumat of Economiss, May 1970.
} 
5. Government controls. Governments historically have imposed ceilings on interest rates. When such ceilings exist, interest rates cannot be used simultaneously as an indicator of monetary influence on the economy. An indicator that is not allowed to move with changes in market forces can give misleading and wrong information. This point applies only to the use of legal authority to control interest rates by fiat. The use of standard monetary tools to control interest rates does not, of course, weaken its role as an indicator.

Usually when an interest rate is used to measure monetary influence, it is selected from among those which are not under direct government constraints, For example, the corporate Aaa bond rate, which is used in the statistical tests on the United States, has always been free of legal constraints. However, when the government controls one interest rate, like that which banks can pay on time deposits (Regulation Q), credit flows away from banks and into other financial markets in which the rates are uncontrolled. These distortions in credit flows could distort the interest rate quoted in those markets as an indicator of monetary influence.

It is, of course, possible that interest rate controls on time deposits could distort the money stock, especially when money is defined to include time deposits. However, the money stock definition used here includes only demand deposits and currency, and therefore the distorting effects of controls are apt to be minimized.

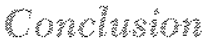

The main point of this article is that selection of an indicator of central bank actions need not be made only on theoretical grounds. If we are not certain of the theoretical structure of the economy, the selection of the indicator can also be made on empirical grounds. We have observed, in a wide range of historical and institutional contexts, that the money stock is a reliable and predictable indicator of monetary influence, and that interest rates are not. The reasons for this difference in results stem largely from the fact that it apparently takes more knowledge about the workings of the economic system to evaluate the impact of interest rates than to evaluate the impact of the money stock. There are at least five possible factors responsible for this: (1) the reported interest rates do not cover all the financial markets which transmit monetary influences to the rest of the economy; (2) the data reported are of nominal interest rates, while it is real interest rates which affect economic activity; (3) it is difficult to distinguish changes in interest rates which are induced by demand pressures of the public from those caused by central bank actions; (4) uncertainty about the demand for commodities relative to the demand for money increases the uncertainty of the relation of interest rates to economic activity; (5) Government interest rate ceilings in some markets induce arbitrage flows which distort the movements of interest rates in other markets.

We can summarize these factors by saying that they represent the greater degree of knowledge we must have about the economic system to make interest rates a successful indicator of monetary influence on economic activity. This does not imply that the money stock is not subject to some of the same uncertainties as those attached to interest rates. Rather, the statistical results suggest that the uncertainties are less with the money stock than with interest rates.

This article is available as Reprint No. 59 


\section{STATISTICAL APPENDIX}

The following tables summarize the regression results which are the basis for the assertions in the text. The only aspect of these results which is discussed in the text are the " $t$ " values on the alternative monetary variables. There are other implications which can be drawn from these results. Specifically, the fiscal variables play a stronger role and have greater statistical significance when an interest rate, rather than the money stock, is used as the monetary variable. This result is not surprising. Omitting money from the equation allows the Govermment deficit to be financed by increases in the money stock rather than just through increases in debt sales to the public. Thus, following the analysis of Fand (this Review, January 1970), one would expect a stronger measured fiscal inflnence when interest rates are the monetary variable, and a weak fiscal influerce when the money stock is the monetary variable. This point and others will be developed in a future article.

The Almon lag technique was used to estimate all equations presented below. By constraining the distribution of coefficients to fit a polynomial curve of $\mathrm{n}$ degree, it is designed to avoid the bias in estimating distributed lag coefficients which may arise from multicollinearity in the lag values of the independent variables. The theoretical justification for this procedure is that the Almon constrained estimate is superior to the unconstrained estimate, because it will create a distribution of coefficients which more closely approximates the disw tribution derived from a sample of infinite size. In order to minimize the severity of the Almon constraint, the maximum degree of the polynomial was used in each case. The maximum degree is equal to the number of lags

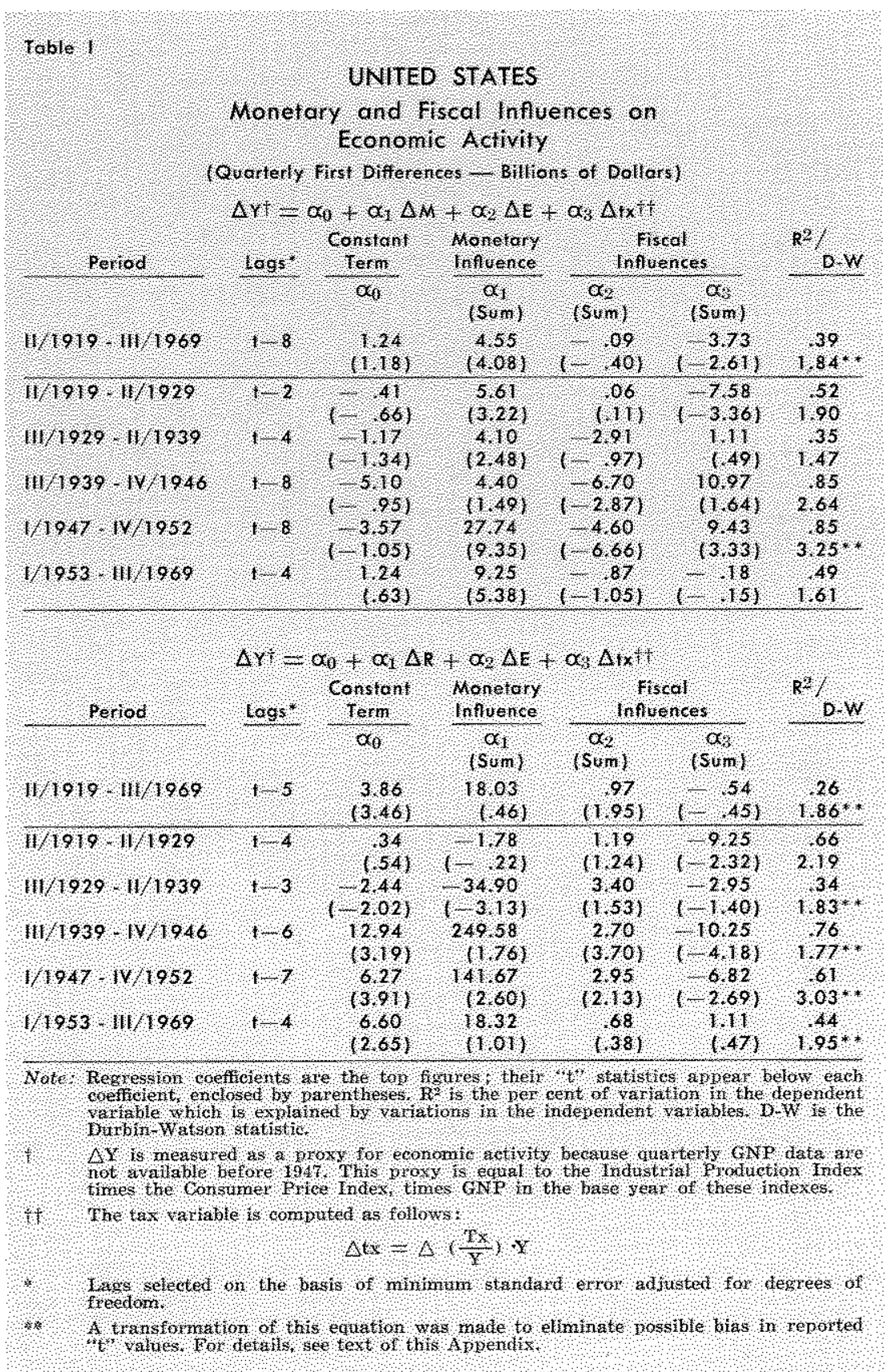


plus one of the independent variables up to five lags. If there are $n$ lags, $t+1$ and $t-n-1$ are both constrained to equal zero. The regressions were also run without constraining the beginning and ending values to zero, and the results are virtually identical.

The Durbin-Watson (D-W) statistic is constructed to equal $2(1-\hat{\rho})$, where it is hypothesized that the error

1This follows the convention established by Shirley Almon,

"The Distributed Lag Between Capital Appropriations and Expenditures," Econometrica, January 1965, term $\varepsilon_{\mathrm{t}}$ equals $\left[\rho \cdot \varepsilon_{\mathrm{t}-1}+\mu_{\mathrm{i}}\right]$ with $\mathrm{k}_{\mathrm{t}}$ normally distributed. In the cases where the D-W statistic is significantly greater or less than 2 , autocorrelation in the error term is indicated, and the "t" values of the coefficients will be biased. In such cases, unbiased estimates of the " $\mathrm{t}$ " values can be obtained by transforming the original equation,

$$
Y_{t}=\alpha_{0}+\sum_{i=1}^{n} \alpha_{i} X_{i, i}
$$

into $\left(Y_{t}-\rho Y_{t-1}\right)=\alpha_{0}(1-\rho)+\sum_{i=1}^{\mathrm{n}} \alpha_{i}\left(X_{t, i}-\rho X_{i-1, i}\right)$,

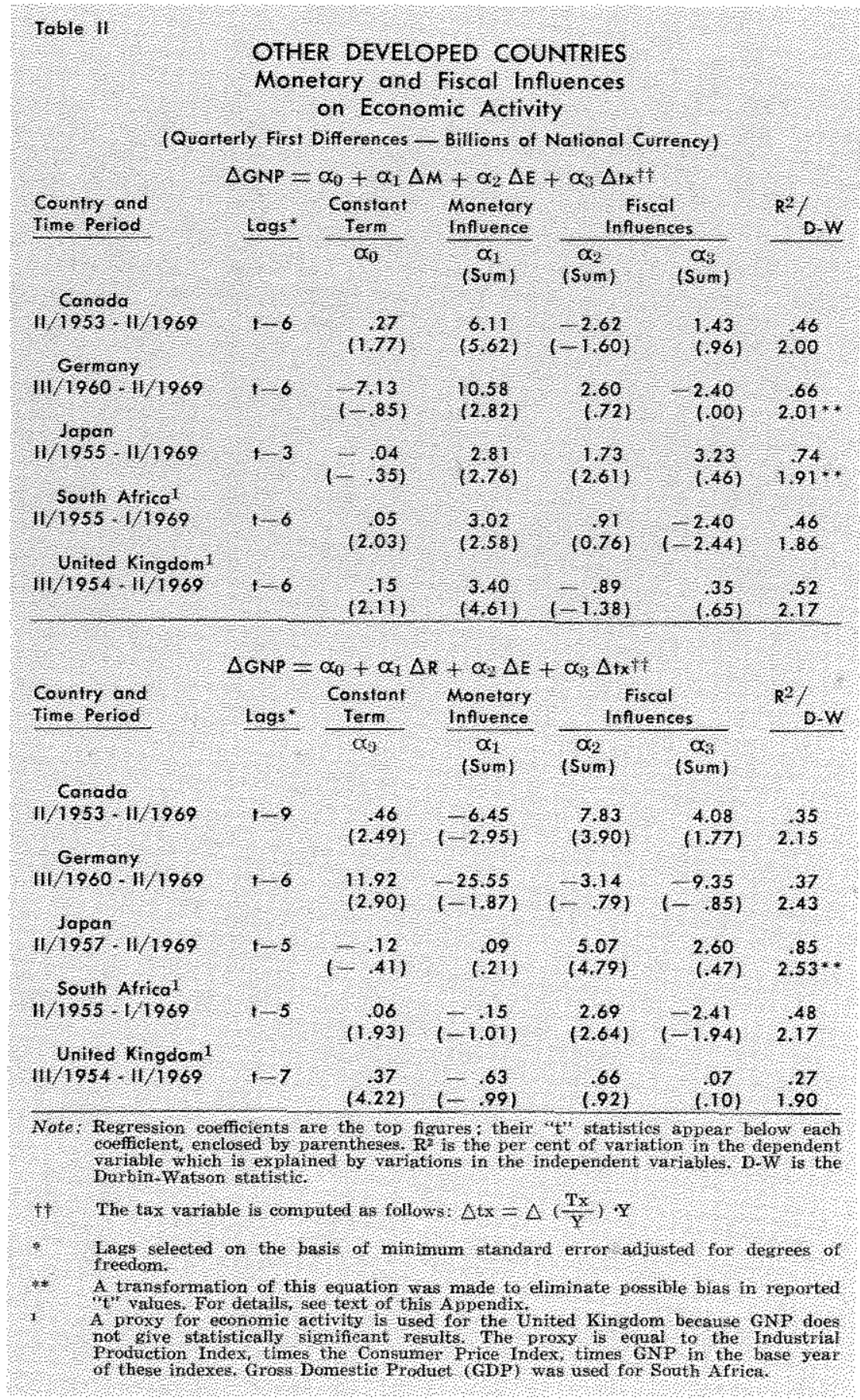

and using the " $t$ " values obtained from the latter form. Those cases where the " $t$ " values of the transformed equation were used are starred (*) next to their respective D-W statistics. In these cases the results reported from the transformed equation are the "fE" and $D-W$ values. The values of the coefficients and $\mathrm{R}^{2}$ are from the original equation. ${ }^{2}$

\section{Data Sounces}

Canada - Gross National Product: Canadian Statistical Reviet, Dominion Bureau of Statistics; Money Stock: International Financial Statistics, IMF; Interest Rates (Long-term Government Bond Yield): Intemational Financial Statistics, IMF; Government Receipts and Expenditures: Canadian Statistical Review, Dominion Bureau of Statistics.

Germany - Gross National Product: International Financial Statistics, IMF; Money Stock: Intemational Financial Statistics; IMF; Interest Rates (Mortgage Bond Yield): International $F i$ nancial Statistics, IMF; Government Receipts and Expenditures (Federal finance on a cash basis): Monthly Report of the Deutsche Bundesbank.

Japan-Gross National Product: Annual Report on National Income Statistics, Economic Planning Agency of Japan and Nihon Keizai Shimbun; Money Stock: Economic Statistics Monthly, Bank of Japan; Interest Rates (Bank Lending Rate); Main Economic Indicators, OECD; Government Receipts (Tax and Stamp Revenue) and Government Expenditures (Treasury Cash Payments): Basic Data for $E_{C O}-$ nomic Analysis 1964, 1968, 1969, and Economic Statistics Monthly. Statistics Department of the Bank of Japan.

2See Arthur S. Goldberger, Econometric Theory, (New York: John Wiley and Sons, 1964$)$ pp. $236-8$ for further discussion. 
Table III

UNITED STATES

Monetary and Fiscal Influences on Economic Activity

(Quarterly First Differences - Billions of Dollars) ${ }^{1}$

\begin{tabular}{|c|c|c|c|c|c|c|}
\hline \multirow[t]{2}{*}{ Period } & \multirow[t]{2}{*}{$\begin{array}{l}\Delta \gamma^{\dot{i}}= \\
\text { Lags* }\end{array}$} & \multirow{2}{*}{$\begin{array}{c}\alpha_{0}+\alpha_{1} \\
\text { Constant } \\
\text { Term }\end{array}$} & \multirow{2}{*}{$\begin{array}{c}\begin{array}{c}\text { Monetary } \\
\text { Influence }\end{array} \\
\alpha_{1} \\
\text { (Sum) }\end{array}$} & \multicolumn{2}{|c|}{$\begin{array}{c}\text { Fiscal } \\
\text { Influences }\end{array}$} & \multirow[t]{2}{*}{$R^{2} / \mathrm{D}-W$} \\
\hline & & & & $\begin{array}{c}\alpha_{2:} \\
\text { (Sum) }\end{array}$ & $\begin{array}{c}\alpha_{:} \\
(\text {Sum })\end{array}$ & \\
\hline $11 / 1919 \cdot 111 / 1969$ & $t-5$ & $\begin{array}{l}2.37 \\
(.53)\end{array}$ & $\begin{array}{c}.38 \\
(.42) \\
\end{array}$ & $\begin{array}{c}.96 \\
(1.81) \\
\end{array}$ & $\begin{array}{r}.54 \\
(\quad .501 \\
\end{array}$ & $\begin{array}{l}.26 \\
1.86 * *\end{array}$ \\
\hline $11 / 1919-11 / 1929$ & $t-4$ & $\begin{array}{l}1.13 \\
(.15)\end{array}$ & $\left(\begin{array}{l}.16 \\
(\cdots .11)\end{array}\right.$ & $\begin{array}{l}(.17 \\
(.82)\end{array}$ & $\begin{array}{c}10.04 \\
(-2.63)\end{array}$ & $\begin{array}{r}.65 \\
2.16\end{array}$ \\
\hline $111 / 1929-11 / 1939$ & $1-4$ & $\begin{array}{l}3.02 \\
(.40)\end{array}$ & $\begin{array}{r}1.37 \\
(-\quad .76)\end{array}$ & $\begin{array}{c}4.41 \\
(1.44)\end{array}$ & $\begin{array}{c}-3.55 \\
(-1.35)\end{array}$ & $\begin{array}{r}.31 \\
1.84\end{array}$ \\
\hline $111 / 1939-1 V / 1946$ & $1-6$ & $\begin{array}{r}128.62 \\
(3.41)\end{array}$ & $\begin{array}{c}-43.65 \\
(-3.12)\end{array}$ & $\begin{array}{c}3.86 \\
(6.06)\end{array}$ & $\begin{array}{c}12.07 \\
(-5.99)\end{array}$ & $\begin{array}{r}.84 \\
2.21\end{array}$ \\
\hline $1 / 1947-1 V / 1952$ & $1 \cdot-8$ & $\begin{array}{r}-304.38 \\
(-.19)\end{array}$ & $\begin{array}{c}115.10 \\
(.17)\end{array}$ & $\begin{array}{l}2.78 \\
(.77)\end{array}$ & $\begin{array}{c}9.25 \\
(-1.53)\end{array}$ & $\begin{array}{r}.59 \\
2.78 *\end{array}$ \\
\hline $1 / 1953-111 / 1969$ & $1-6$ & $\begin{array}{r}28.66 \\
(-4.13) \\
\end{array}$ & $\begin{array}{r}9.74 \\
(5.19) \\
\end{array}$ & $\begin{array}{c}1.74 \\
\left(\begin{array}{l}1.75 \\
(\end{array}\right)\end{array}$ & $\begin{array}{l}-1.02 \\
(-.70)\end{array}$ & $\begin{array}{r}.63 \\
1.97\end{array}$ \\
\hline
\end{tabular}

OTHER DEVELOPED COUNTRIES

(Quarterly First Differences - Billions of National Currency) ${ }^{1}$

\begin{tabular}{|c|c|c|c|c|c|c|}
\hline \multirow{3}{*}{$\begin{array}{l}\text { Country and } \\
\text { Time Period }\end{array}$} & \multicolumn{5}{|c|}{$\Delta \mathrm{GNP}=\alpha_{0}+\alpha_{1} \mathrm{R}+\alpha_{22} \Delta \mathrm{E}+\alpha_{33} \Delta \mathrm{tx}$} & \multirow{3}{*}{$R^{2} / \mathrm{D}-W$} \\
\hline & \multirow[t]{2}{*}{ Lags * } & \multirow{2}{*}{$\begin{array}{c}\begin{array}{c}\text { Constant } \\
\text { Term }\end{array} \\
\alpha_{0}\end{array}$} & \multirow{2}{*}{$\begin{array}{c}\begin{array}{c}\text { Monetary } \\
\text { Influence }\end{array} \\
\alpha_{1} \\
\text { (Sum) }\end{array}$} & \multicolumn{2}{|c|}{$\begin{array}{c}\text { Fiscal } \\
\text { Influences }\end{array}$} & \\
\hline & & & & $\begin{array}{c}\alpha: z \\
\text { (Sum) }\end{array}$ & $\begin{array}{c}\alpha: \\
(S u m)\end{array}$ & \\
\hline $\begin{array}{l}\text { Canada } \\
11 / 1953-11 / 1969\end{array}$ & $1-2$ & $\begin{array}{c}-.69 \\
(--1.34)\end{array}$ & $\begin{array}{c}.28 \\
(2.44)\end{array}$ & $\begin{array}{l}1.20 \\
(1.14)\end{array}$ & $\begin{array}{c}.92 \\
(1.28)\end{array}$ & $\begin{array}{r}.30 \\
1.68\end{array}$ \\
\hline $\begin{array}{l}\text { Germany } \\
\text { III/1960-11/1969 }\end{array}$ & $1-7$ & $\begin{array}{r}4.16 \\
(-\quad .24)\end{array}$ & $\begin{array}{c}2.66 \\
(1.02)\end{array}$ & $\begin{array}{l}-4.03 \\
(-.99)\end{array}$ & $\begin{array}{r}-2.83 \\
(-.24)\end{array}$ & $\begin{array}{r}.34 \\
2.50\end{array}$ \\
\hline $\begin{array}{l}\text { Japan } \\
11 / 1957 \cdot 11 / 1969\end{array}$ & $1--5$ & $\begin{array}{r}2.96 \\
11.60\end{array}$ & $\begin{array}{c}.37 \\
1.701\end{array}$ & $\begin{array}{c}4.20 \\
(3.53)\end{array}$ & $\begin{array}{l}3.62 \\
(.61)\end{array}$ & $\begin{array}{r}.84 \\
2.51\end{array}$ \\
\hline $\begin{array}{l}\text { South Africa } \\
11 / 1955-1 / 1969\end{array}$ & $1-6$ & $\begin{array}{l}-.09 \\
(-1.34)\end{array}$ & $\begin{array}{c}.04 \\
(2.22)\end{array}$ & $\begin{array}{c}3.20 \\
\{4.15\}\end{array}$ & $\begin{array}{l}\cdots 3.10 \\
(\cdots 2.69)\end{array}$ & $\begin{array}{r}.47 \\
1.93\end{array}$ \\
\hline $\begin{array}{l}\text { United Kingdo } \\
111 / 1954 \cdot 11 / 196\end{array}$ & $1-8$ & $\begin{array}{c}-1.03 \\
(-2.31)\end{array}$ & $\begin{array}{c}.30 \\
(3.22)\end{array}$ & $\begin{array}{c}-1.49 \\
(-1.53)\end{array}$ & $\begin{array}{c}.86 \\
(1.11)\end{array}$ & $\begin{array}{r}.40 \\
2.38\end{array}$ \\
\hline
\end{tabular}

Note: Regression coefficients are the top figures; their " $t$ " statistics anpear below each

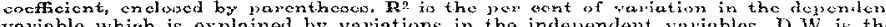
variable Which is explained by variations in the independent variables. 1).W is the

$\dagger \triangle \mathrm{Y}$ is measured as a proxy for economic activity hecause quarterly CNP data for the U.S. are not available hefore 1947 , and because quarterly GNP data for the U.K. do not give statistically signifieant results. The proxy is equal to the Industrial Production lndex, times the Consumer Priee Index, limes GNP in the base

ti The tax variable is computed as follows:

$$
\Delta \mathrm{tx}=\Delta\left(\frac{\mathrm{T} \mathrm{x}}{\mathrm{Y}}\right) \cdot \mathrm{y}
$$

* Lags selected on the basis of minimum standard error adjusted for degrees of freedom.

\#* A transformation of this equation was made to eliminate possible bias in reported " $t$ " values. For details, see text of this Appendix.

Levels are used for interest rate data.
South Africa - Gross Domestic Product: South Africa Review, Government of South Africa; Money Stock: International Financial Statistics, IMF; Interest Rates (Treasury Bill Rate) International Financial Statistics, IMF; Government Receipts and Expenditures: International Financial Statistics, IMF.

United Kingdom - Industrial Production Index and Consumer Price Index, $1963=100$ : Main Economic Indicators, OECD; Money Stock: International Financial Statistics, IMF; Interest Rates (Long-term Government Bond Yield): International Financial Statistics, IMF; Government Receipts and Expenditures: International Financial Statistics. IMF.

United States - Industrial Production Index, 1957-59=100: Board of Governors of the Federal Reserve System; Consumer Price Index, 1957-59= 100: United States Department of Labor; Money Stock: Board of Governors of the Federal Reserve System and the Federal Reserve Bank of St. Louis; Government Receipts and Expenditures: Daily Treasury Statement, Office of the Secretary of the Treasury of the United States and Federal Reserve Bank of St. Louis.

In each case, the seasonally adjusted series for gross national produrt, grose domestic product, money stock, government expenditures and government receipts were used. The interest rate series are not seasonally adjusted.

The seasonally adjusted industrial production index and the unadjusted consumer price index were used in the construction of the proxy variable (Y) which was used for the United States and the United Kingdom. 